Carroñeo de cadáveres de tortuga marina por multiples jaguares en el Noroeste de Costa Rica

\title{
Scavenging on sea turtle carcasses by multiple jaguars in Northwestern Costa Rica
}

\author{
Sergio Escobar-Lasso ${ }^{1,2 *}$ Margarita Gil-Fernández ${ }^{1}$, Hansel Herrera ${ }^{1}$, Luis G. Fonseca ${ }^{3}$, Eduardo Carrillo-Jiménez ${ }^{1,4}$, Joel \\ Sáenz ${ }^{1}$, and Grace Wong ${ }^{1}$

\begin{abstract}
${ }^{1}$ Instituto Internacional en Conservación y Manejo de Vida Silvestre. ICOMVIS. Universidad Nacional de Costa Rica. Heredia, Costa Rica. E-mail: biosergiobike@gmail.com (SE-L), mgilfedz@gmail.com (MG-F), bluecloudcr@gmail.com (HH), jsaenz@una.cr (JS), icomvis@una.cr (GW).

${ }^{2}$ Fundación R.A.N.A. (Restauración de Ambientes Neotropicales Alterados). Heredia, Costa Rica. E-mail: biosergiobike@gmail.com ${ }^{3}$ Biocenosis Marina, Trinidad de Moravia. San José, Costa Rica. E-mail: luisfonsecalopez@gmail.com (LGF).

${ }^{4}$ Programa Jaguar, Universidad Nacional de Costa Rica. Heredia, Costa Rica. E-mail: icomvis@una.cr (EC-J).

*Corresponding author
\end{abstract}

\begin{abstract}
Information on scavenging by jaguars is scarce, dispersed and little documented in the scientific literature, producing a shallow understanding of this phenomenon. Therefore, the aim of this paper is to describe the behavior of multiple jaguars scavenging on single carcasses of olive ridley sea turtles (Lepidochelys olivacea) that died by jaguar predation. The study was conducted at two beaches (Naranjo and Nancite) within the Santa Rosa National Park, Costa Rica. We carried out morning walks on Naranjo and Nancite beaches. We set up camera traps to capture the full extent of the feeding behavior on fresh jaguar-predated turtles. We recorded two scavenging events. The jaguars involved in the two scavenging events dragged or tried to drag the sea turtle carcass to a new location. This behavior could suggest the presence of intraspecific kleptoparasitism. However, further investigation of this type is required to determine the existence of kleptoparasitism, and also to get a deeper understanding of scavenging in jaguars and its relation to prey availability.
\end{abstract}

La información sobre el carroñeo por múltiples jaguares es escasa, dispersa y poco documentada en la literatura científica, esto produce un entendimiento superficial del fenómeno. Por lo tanto, el objetivo de este trabajo es describir el comportamiento de varios jaguares que carroñean sobre un mismo cadáver de tortuga lora (Lepidochelys olivacea) que murieron por la depredación de jaguar. El estudio se realizó en dos playas (Naranjo y Nancite) dentro del Parque Nacional Santa Rosa, Costa Rica. Hemos llevado a cabo caminatas diurnas en las playas Naranjo y Nancite. Instalamos cámaras trampa para capturar toda la extensión de la conducta alimentaria de jaguar al depredar tortugas marinas. Se registraron dos eventos de carroñeo. Todos los jaguares que participan en los dos eventos de carroñeo intentaron robar y esconder el cadáver de la tortuga marina. Este comportamiento sugiere la presencia de cleptoparasitismo intraespecífico, sin embargo, se requiere más investigación de este tipo para determinar si el cleptoparasitismo existe y, además, lograr un entendimiento más profundo del carroñeo en jaguares y sus relaciones con la disponibilidad y abundancia de las presas.

Key words: carrion; Lepidochelys olivacea; Panthera onca; predation; sea turtles; sharing kills.

๑) 2016 Asociación Mexicana de Mastozoología, www.mastozoologiamexicana.org

\section{Introduction}

Pereira et al. (2013) distinguished four ways whereby mammalian carnivores secure their food: 1. Additive predation (i. e. killing healthy animals); 2. Compensatory predation (i. e. preying on young, old or sick animals that are vulnerable to mortality from other causes, and thereby promoting the survival of the remainder of the prey population); 3. Kleptoparasitism (i. e. displacing other carnivores from their kills); and 4. Scavenging, that is feeding on the remains of kills by other predators, or on animals that have died from disease, malnutrition, or other causes. Mammalian carnivores can exhibit several or even all of these feeding patterns, which shows that there may be a continuum between predatory versus scavenging strategies not only at the interspecific but also at the intraspecific level (Wilson and Wolkovich 2011; Pereira et al. 2013). By definition, scavengers feed on the remains of animals that have died (i. e. carrion), while predators kill animals in order to feed on the resulting 
carcasses (Pereira et al. 2013). The carcasses can be consumed by an individual or shared by several individuals, depending on the behavior of the species and the abundance and availability of the prey and carcasses (DeVault et al. 2003; Wilson and Wolkovich 2011; Pereira et al. 2013). One of the challenges faced by most mammalian carnivores is to secure a regular supply of food, especially if the natural susceptibility of animals to die or to be killed varies seasonally and spatially (DeVault et al. 2003). As a result, most large mammalian carnivores shift facultatively between hunting and scavenging depending on seasonal and regional variation of prey availability (Wilmers et al. 2003; Wilson and Wolkovich 2011; Pereira et al. 2013). A clearer perspective on carrion use by mammalian carnivores will improve our understanding of critical ecological processes, particularly those associated with energy flow and trophic interactions between individuals and species (DeVault et al. 2003).

Mammalian carnivores are traditionally labeled as predators, but they do not usually pass by opportunities to consume carcasses when encountered (DeVault et al.2003; Selva et al. 2005; Wilson and Wolkovich 2011). No mammals have evolved into obligate scavengers and even the most well adapted mammalian scavengers, such as hyenas, kill the majority of their food (Cooper et al. 1999). Thus, all mammals that feed on carrion are considered facultative scavengers (Pereira et al. 2013). Indeed, what we find in nature is a quite continuous gradient from the most genuine predators that kill by themselves most of their prey (e. g. cheetah Acinonyx jubatus) to those which consume mostly carrion (e. g. brown hyaena Hyaena brunnea; Skinner and Chimimba 2005). Therefore, the conventional distinction between predators and scavengers may be confusing with regard to the interspecific interactions and the energy fluxes taking place within food webs (Wilson and Wolkovich 2011; Pereira et al. 2013). Facultative scavenging represents a type of multi-channel feeding that could be an important stabilizing force in many food webs, as suggested by recent theory (Wilson and Wolkovich 2011).

Scavenging by species of cats (Felidae) has rarely been reported, and most long-term studies suggest that they prefer eating their own kills (DeVault et al. 2003; Bauer et al. 2005; Cavalcanti and Gese 2010). Wild felids are more obligate hunters and consume less carrion compared with canids, hyenids, ursids or mustelids (Pereira et al. 2013). Field observations of carrion consumption by large wild cats have been recorded but infrequently described in the scientific literature (Castañeda et al. 2013).

Of the 12 species of American wild cats, only two species (cougars Puma concolor and jaguars Panthera onca) have been recorded scavenging (Ross and Jalkotzy 1996; Bauer et al. 2005; Castañeda et al. 2013). In cougars the behavior where several individuals share carcasses has been widely documented (Ross and Jalkotzy 1996; Bauer et al. 2005; Bacon and Boyce 2010; Knopff et al. 2010). But, information on scavenging by jaguars is scarce, scattered, and little documented in the scientific literature. Moreover, there has not been a literature review on the subject (González and Piña 2002; Cavalcanti and Gese 2010; Castañeda et al. 2013; Guilder et al. 2015). Therefore, the aim of this paper is to describe the behavior of multiple jaguars scavenging on carcasses of olive ridley sea turtles (Lepidochelys olivacea) at Santa Rosa National Park, Costa Rica.

\section{Materials and methods}

Study site. The study was conducted at two beaches (Naranjo and Nancite) within the Santa Rosa National Park (SRNP), Costa Rica. The SRNP covers 38,628 ha and it is part of a continuous block of 163,000 ha of protected land known as the Guanacaste Conservation Area (www.acguanacaste. ac.cr). The SRNP protects one of the best preserved dry forests of Central America. The Naranjo and Nancite valleys preserve mainly coastal-marine ecosystems (i.e. mangroves, lagoons and dry deciduous and semi-deciduous forests), including two important nesting beaches for the green 
(Chelonia mydas), olive ridley (Lepidochelys olivacea) and leatherback (Dermochelys coriacea) sea turtles (Cornelius 1986; Bernardo and Plotkin 2007; Fonseca et al. 2009).

The Naranjo and Nancite beaches (Figure 1) are located in the southwestern part of SRNP and have a length of 5,640 $\mathrm{m}$ and 1,050 $\mathrm{m}$ respectively. These beaches are separated from one another by a rocky mountain $(\sim 500 \mathrm{~m})$. Naranjo beach is fully opened to local and international tourists. On the contrary, Nancite has been protected from intrusive human activities, including tourism and supports an intact wild ecosystem. Nancite beach is well known for the olive ridley sea turtle "arribada" phenomenon (Cornelius 1986; Fonseca et al. 2009). This phenomenon consists of the massive synchronous nesting of hundreds or thousands of olive ridleys over a few consecutive nights (Cornelius 1986; Bernardo and Plotkin. 2007; Fonseca et al. 2009). This event also occurs at beaches in Mexico (La Escobilla and El Morro Ayuta), Costa Rica (Ostional), and India (Gahirmatha and Rushikulya), with minor arribada beaches also present in Nicaragua (La Flor and Chacocente) and in Panama (Isla Cañas) (Bernardo and Plotkin 2007).

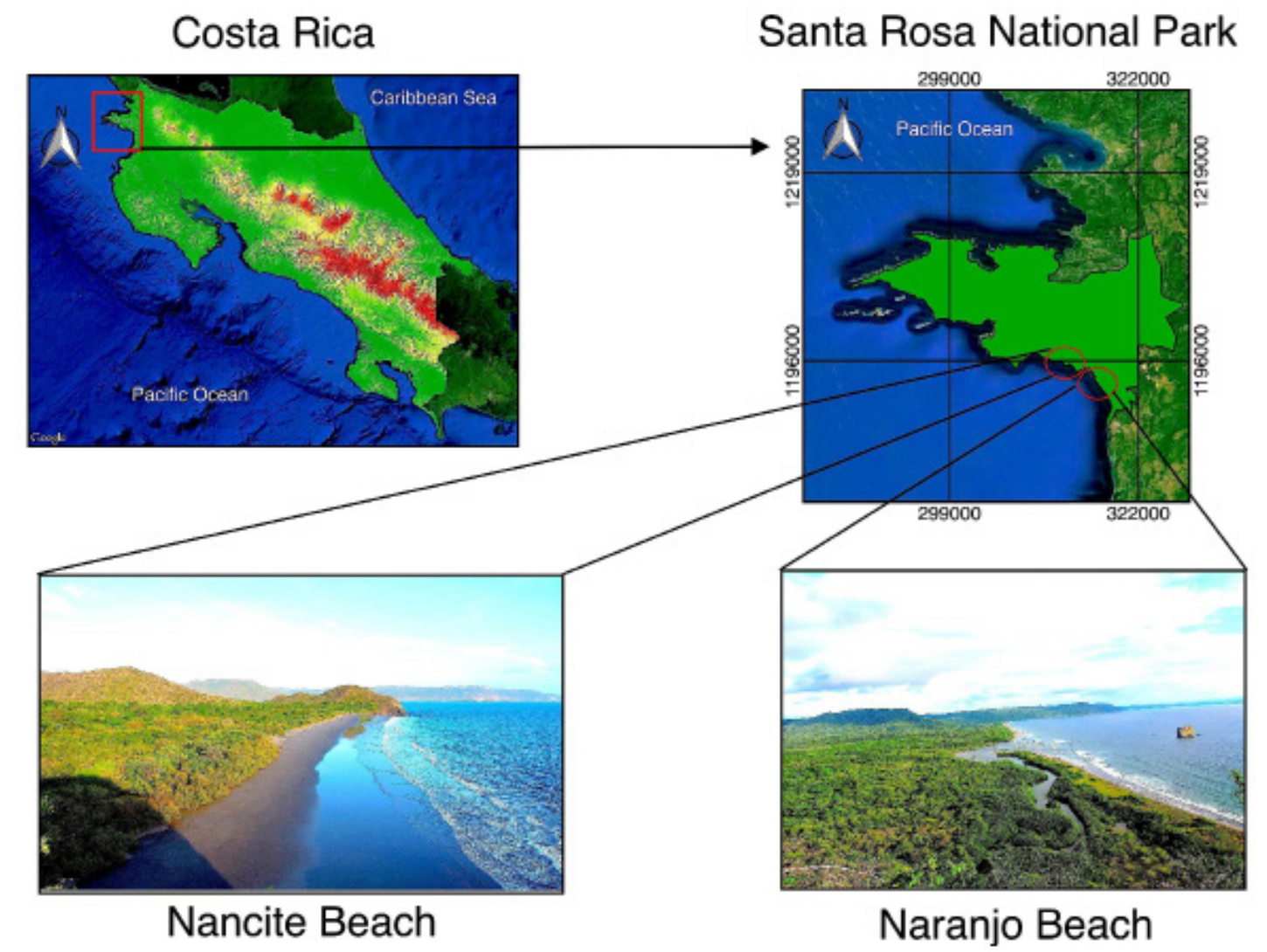

Figure 1. Location of Naranjo and Nancite Beaches, Santa Rosa National Park, Costa Rica.

Data collection. As part of a jaguar-sea turtle research project, we carried out morning walks on Naranjo and Nancite beaches. Upon encountering a freshly predated turtle, we set up camera traps to capture the full extent of the jaguar feeding behavior. We distinguished the jaguar predated turtles from those killed by other predators (like American crocodiles or humans) by a set of distinctive characteristics such as bite marks on the neck of the turtle and its front flippers (see Veríssimo et al. 2012). To prevent jaguars (and other scavengers) from moving the kill to a new site, we tied the carcasses to a nearby tree. Thanks to monitoring activities of jaguars at SRNP for several years, we were able to document if the jaguars are related or not (unpublished work). Therefore, when we recorded multiple jaguars scavenging on the same carcass we classified each event according to whether or not it involved individuals with direct relationships. Direct relations 
could be defined as: A) when a female has cubs, B) when the cubs leave their mother, but can remain together for a period of time, and C) when a female is in estrous and walks with a male at her side (Sunquist and Sunquist 1989; Harmsen et al. 2009). In contrast, we considered that the individuals are unrelated when they do not demonstrate any family or reproductive relationship (Sunquist and Sunquist 1989; Harmsen et al. 2009). If the individuals are related directly, the sharing of kills is not a surprising fact, and for this reason it is important to establish if prey sharing is happening in another context. It is of course possible that seemingly unrelated individuals could in fact be related.

\section{Results and discussion}

The first scavenging event was recorded on December $26^{\text {th }}, 2014$ at Naranjo beach $\left(10^{\circ} 45^{\prime} 27.60^{\prime \prime}\right.$ $\mathrm{N}, 85^{\circ} 39^{\prime} 46.82^{\prime \prime} \mathrm{W}$ ). On December $25^{\text {th }}$ Erick Alguera (a team member) found a freshly killed turtle which had been dragged $30 \mathrm{~m}$ into the vegetation and was surrounded by jaguar footprints. He, immediately, set up a camera trap equipped with video recording technology which remained functional for four days until removed from the site on December $29^{\text {th }}$. The videos revealed that on December $26^{\text {th }}$ two seemingly unrelated female jaguars visited the carcass between 19:44 and 21:53 h (Figure 2). These jaguars had been previously captured and equipped with satellite transmitters, which made individual identification easy. The jaguars visited the carcass one at a time, $1 \mathrm{~h}$ and $31 \mathrm{~min}$ apart from each other. The first individual (equipped with a white collar) spent 38 min with the carcass and consumed large amounts of meat from the neck and front flippers. The second individual (equipped with a black collar) stayed for 14 min and consumed small portions of meat from the rear flippers. Unfortunately, it is impossible for us to identify the jaguar that acted as predator; in this case. It could have been either one of the observed females or even an unrecorded individual.

The second scavenging event was recorded on $26^{\text {th }}$ November 2015 at Nancite beach $\left(10^{\circ} 48^{\prime}\right.$ $\mathrm{N}$ and $85^{\circ} 39^{\prime} \mathrm{W}$ ). The turtle, which had been dragged $10 \mathrm{~m}$ into the vegetation, was found by Escobar-Lasso on November $25^{\text {th }}$ and equipped with two camera traps. The cameras remained functional for three days until removed on November $28^{\text {th }}$. In this case, three individuals (one male and two females) visited the carcass between 16:20 and 00:09 $\mathrm{h}$ (Figure 3). The jaguars fed on the turtle one at a time and were distinguished from one another by their coat pattern. According to our records, both the first (Figure $3 \mathrm{AB}$ ) and the second (Figure 3CD) individuals were juvenile sisters, while the third individual was an unrelated adult male (Figure 3EF). The time intervals between the visits of the three individuals were one hour between the first and second individual and five hours between the second and third individual. The time spent on the carcass was 12, 87 , and 8 minutes for the first, second and third jaguars, respectively. The first and second jaguars consumed large amounts of meat from the neck and front flippers, while the third jaguar only consumed small portions of meat of the rear flippers. As in the previous case, we cannot tell the predator from the scavengers, but at least two individuals were acting as scavengers this time.

Jaguars are considered opportunistic predators whose diet includes more than 85 species (Aranda and Sánchez-Cordero 1996; Chinchilla 1997; Garla et al. 2001; Sunquist and Sunquist 2002; Hernández 2008; Silveira et al. 2010). As with other elusive carnivores, the scientific community is still learning about the broad diet and hunting strategies of jaguars. New prey species, food habits, hunting strategies, kill rates, and predation patterns are described regularly (Taber et al.Taber et al. 1997; Núñez et al. 2000; Garla et al. 2001; Sunquist and Sunquist 2002; Polisar et al. 2003; Novack et al. 2005; Weckel et al. 2006; Azevedo and Murray 2007; Carrillo et al. 2009; Cavalcanti and Gese 2010). The hunting strategies of jaguars include scavenging as well as additive and compensatory predation (Schaller and Crawshaw 1980; González and Piña 2002; Sunquist and Sunquist 2002; Cavalcanti and Gese 2009; Castañeda et al. 2013; Pereira et al. 2013; Guilder et al. 2015). 
Information on scavenging by jaguars is scarce, since only five scientific publications have reported scavenging behavior (see González and Piña 2002; Cavalcanti and Gese 2010; Castañeda et al. 2013; Guilder et al. 2015; this work). From 415 kill sites located for 10 radio-collared jaguars at El Pantanal Brazil, Cavalcanti and Gese (2010) reported

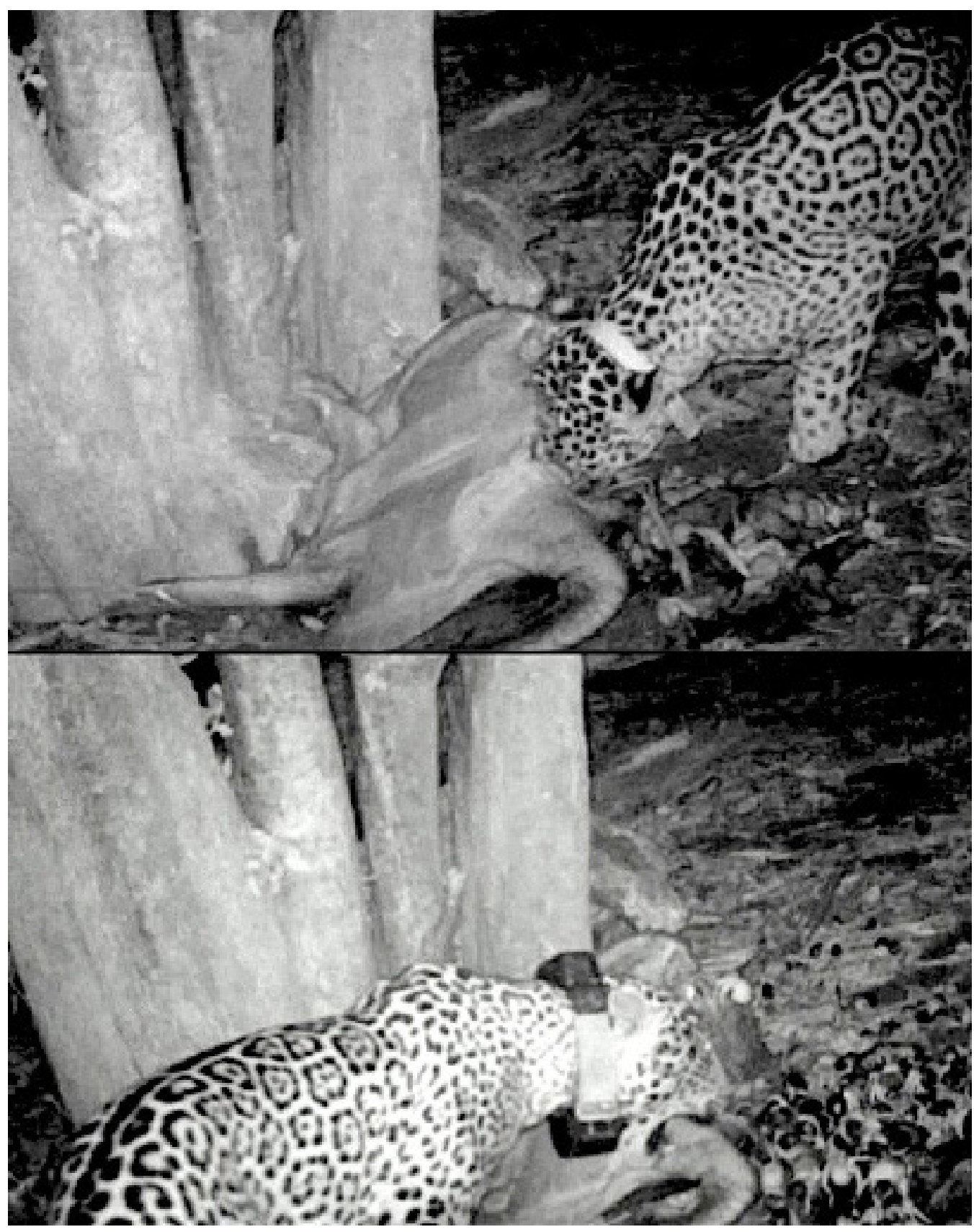

Figure 2. Two unrelated female jaguars scavenging on the same carcass of an olive ridley sea turtle Lepidochelys olivacea, at Naranjo beach, Santa Rosa National Park, Costa Rica. Photo: Erick Alguera.

only 6 scavenging events (1.5\%), all of which involved cattle. In addition, camera traps have been employed to document a male and female jaguar scavenging on an adult cow carcass in México (González and Piña 2002), and two males were observed scavenging on an unidentified species of marine dolphin (Delphinidae) carcass in Honduras (Castañeda et al. 2013). Guilder et al. (2015) recorded jaguars scavenging on multiple sea turtle carcasses that were killed by jaguars at Tortuguero National 
Park, Costa Rica. Castañeda et al. (2013) suggested that scavenging might play a more important role in the diet of jaguars than previously documented.

Seasonal fluctuations in prey availability often trigger temporary alterations in individual jaguars hunting behavior and in the exploitation of alternative prey species (Carrillo et al. 2009; Cavalcanti and Gese 2010). Of the five scientific manuscripts that reported scavenging behavior in jaguars (González and Piña 2002; Cavalcanti and Gese 2010; Castañeda et al. 2013; Guilder et al. 2015; this work) only Guilder et al. (2015)) have been able to determine that the scavenging behavior varies among seasons of prey availability. Prey in this case was the green sea turtle (Chelonia mydas). Based on this research (Guilder et al. 2015) and that of others on large carnivorous mammals (see DeVault et al. 2003; Wilson and Wolkovich 2011; Pereira et al. 2013), it is logical to assume that, at the seasons with high abundance and availability of prey, jaguars would prefer to consume their own kills. On the contrary, however, at

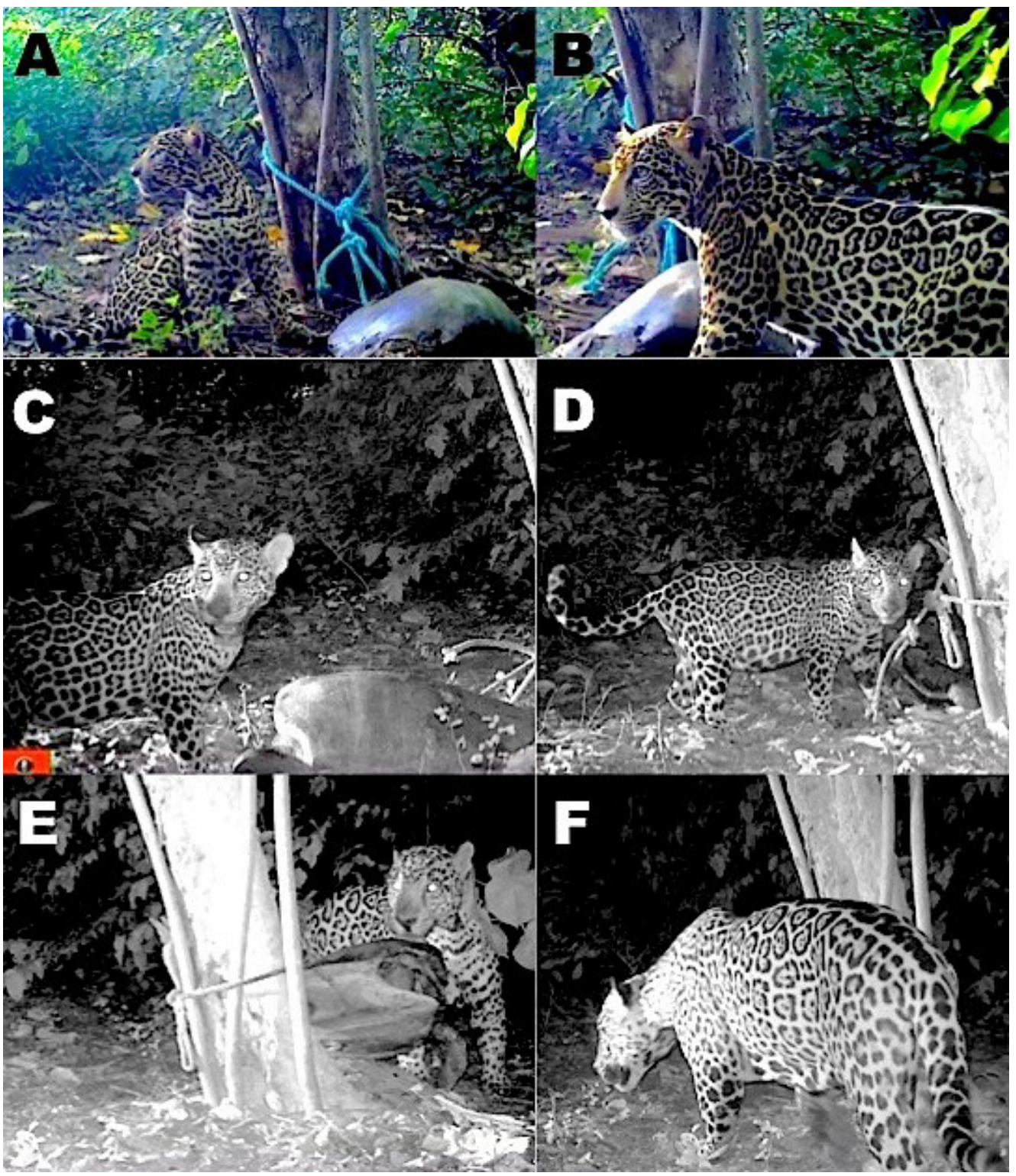

Figure 3. Three different jaguars scavenging on the same carcass of an olive ridley sea turtle Lepidochelys olivacea at Nancite beach, Santa Rosa National Park, Costa Rica. The first (A-B) and second (C-D) individuals were juvenile sisters, while the third individual (E-F) was an unrelated adult male. Photo: Sergio Escobar-Lasso. 
seasons of low abundance and availability of prey the jaguars are tempted to eat carrion and even several individuals can feed from the same carcass. Given the small sample of this study, we are not able to assess the importance of prey availability. However, it is important to highlight that the two scavenging events recorded here were observed at the end of the nesting season of the olive ridley sea turtle when the number of nesting females are scarce (Cornelius 1986; Fonseca et al. 2009). Therefore, it is important to make further investigations to augment our understanding of how scavenging behavior relates to availability of prey.

In mammalian carnivores the behavior of sharing kills or carcasses has different behavioral and social consequences depending on whether it has been done by related or unrelated individuals (Wilson and Wolkovich 2011; Pereira et al. 2013). For example, the sighting of several related jaguars simultaneously feeding on a carcass is commonly observed in situations when there is a group of siblings, a mother with her cubs, or a mated couple (Schaller and Crawshaw 1980; González and Piña 2002; Cavalcanti and Gese 2009; Castañeda et al. 2013). However, the sighting of several unrelated jaguars feeding from a single carcass has never been previously recorded. Guilder et al. (2015) described a couple of jaguars feeding from a sea turtle carcass at the same time, but they do not specify the social relations between them.

An important aspect of our observations, therefore, is the kinship among the jaguars who shared carcasses. Adult jaguars are firmly regarded as solitary hunters (Harmsen et al. 2009). They may maintain exclusive ranges (Azevedo and Murray 2007), although the majority of studies emphasize varying degrees of intrasexual and intersexual range overlap (Rabinowitz and Nottingham 1986; Cavalcanti and Gese 2009; Harmsen et al. 2009). Some of the individuals that we observed cannot be assigned with certainty into any of the social categories in which sharing of carcasses might reasonably be expected. To the extent that some of the individuals observed in this study might be socially unrelated individuals suggests that jaguars, can tolerate shared scavenging as opposed to kleptoparasitism. Thus, this would support the conclusions of Guilder et al. (2015). However, further investigation of this type is required to determine if kleptoparasitism really exists in jaguars, and to more fully understand their scavenging behavior.

\section{Acknowledgements}

We thank E. J. Martinez for peer reviewing this paper and providing valuable comments. This work was made possible by a graduate scholarship from the U. S. Fish and Wildlife Service to S. Escobar-Lasso, H. Herrera and M. Gil-Fernandez.

\section{References}

Aranda, M., And V. Sánchez-Cordero. 1996. Prey spectra of jaguar (Panthera onca) and puma (Puma concolor) in tropical forests of Mexico. Stud Neotrop Fauna and Environm 31:65-67.

Azevedo, F. C. C., AND D. L. Murray. 2007. Spatial organization and food habits of jaguars (Panthera onca) in a floodplain forest. Biological Conservation 137:391-402.

Bacon, M. M., And M. S. Boyce. 2010. Scavenging of an Elk, Cervus elaphus, carcass by multiple Cougars, Puma concolor, in southeastern Alberta. Canadian Field-Naturalist 124:242-245.

Bauer, J. W., K. A. Logan, L. L. Sweanor, and W. M. Boyce. 2005. Scavenging behavior in puma. Southwest Naturalist 50:466-471. 
Bernardo, J., And P. T. Plotkin. 2007. An evolutionary perspective on the arribada phenomenon and reproductive behaviotral polymorphism of olive ridley sea turtles, (Lepidochelys olivacea). In Biology and Conservation of Ridley sea Turtles (Plotki, P. T. , ed.). Johns Hopkins University Press. Baltimore, U. S. A.

Carrillo, E., T. K. Fuller, ANd J. C. Saenz. 2009. Jaguar (Panthera onca) hunting activity: effects of prey distribution and availability. Journal of Tropical Ecology 25:563-567.

Castañeda, F. E., L. A. Herrera, and S. C. Pereira. 2013. Behaviour of two male jaguars scavenging on a marine dolphin in Honduras. Cat News 58:11-12.

Cavalcanti, S. M. C., and E. M. Gese. 2009. Spatial ecology and social interactions of jaguars (Panthera onca) in the Southern Pantanal, Brazil. Journal of Mammalogy 90:935-945.

Cavalcanti, S. M. C., And E. M. Gese. 2010. Kill rates and predation patterns of jaguars (Panthera onca) in the Southern Pantanal, Brazil. Journal of Mammalogy 91:722-736.

Chinchilla, F. A. 1997. La dieta del jaguar (Panthera onca), el puma (Felis concolor) y el manigordo (Felis pardalis) en el Parque Nacional Corcovado, Costa Rica. Revista de Biologia Tropical 45:1223-1229.

Cooper, S. M., K. E. Holekamp, and L. Smale. 1999. A seasonal feast: long-term analysis of feeding behaviour in the spotted hyena (Crocuta crocuta). African Journal of Ecology 37:149-160.

Cornelius, S. E. 1986. The sea turtles of Santa Rosa National Park. Fundación de Parques Nacionales, Costa Rica. Monograph. San José, Costa Rica.

DeVault, T. L., O. E. Rhodes, And J. A. Shivik. 2003. Scavenging by vertebrates: behavioral, ecological, and evolutionary perspectives on an important energy transfer pathway in terrestrial ecosystems. Oikos 102:225-234.

Fonseca, L, G., A. G. Murillo, L. Guadamúz, R. M. Spínola, and R. Valverde. 2009. Downward but stable trend in the abundance of arribada Olive Ridley sea Turtle (Lepidochelys olivacea) at Nancite Beach, Costa Rica (1971-2007). Chelonian Conservation and Biology 8:19-27.

Garla, R. C., E. F. Setz, and N. Gobbi. 2001. Jaguar (Panthera onca) Food habits in atlantic rain forest of southeastern Brazil. Biotropica 33:691-696.

González, C. A. L., And G. L. PiñA. 2002. Carrion use by jaguars (Panthera onca) in Sonora, Mexico. Mammalia 66:603-605.

Guilder, J., B. Barca, S. Arroyo-Arce, R. Gramajo, and R. Salom-Pérez. 2015. Jaguars (Panthera onca) increase kill utilization rates and share prey in response to seasonal fluctuations in nesting green turtle (Chelonia mydas mydas) abundance in Tortuguero National Park, Costa Rica. Mammalian Biology 80:65-72.

Harmsen, B. J., R. L. Foster, S. C. Silver, L. E. T. Ostro, and C. P. Doncaster. 2009. Spatial and temporal interactions of sympatric jaguars (Panthera onca) and pumas (Puma concolor) in a neotropical forest. Journal of Mammalogy 90:612-620.

Hernández, C. G. E. 2008. Dieta, uso de hábitat y patrones de actividad del puma (Puma concolor) y el jaguar (Panthera onca) en la selva Maya, Centroamerica. Revista Mexicana de Mastozoología 12:113-130.

Knopff, K. H., A. A. Knopff, And M. S. Boyce. 2010. Scavenging makes cougars susceptible to snaring at wolf bait stations. Journal of Wild Life Management 74:644-653.

Novack, A. J., M. B. Main, M. E. Sunquist, AND R. F. Labisky. 2005. Foraging ecology of jaguar (Panthera onca) and puma (Puma concolor) in hunted and non-hunted sites within the Maya Biosphere Reserve, Guatemala. Journal of Zoology London 267:167-178.

NúNEez, R., B. Miller, And F. Lindzey. 2000. Food habits of jaguars and pumas in Jalisco, Mexico. Journal of Zoology London 252:373-379. 
Pereira, L. M., N. Owen-Smith, And M. Moleon. 2013. Facultative predation and scavenging by mammalian carnivores: seasonal, regional and intra-guild comparisons. Mammal Review 44: 44-55.

Polisar, J., I. Maxit, D. Scognamillob, L. Farrell, M. E. Sunquist, and J. F. Eisenberg. 2003. Jaguars, pumas, their prey base, and cattle ranching: ecological interpretations of a management problem. Biological Conservation 109:297-310.

Rabinowitz, A., AND B. Nottingham. 1986. Ecology and behavior of the jaguar (Panthera onca) in Belize, Central America. Journal of Zoology 210:149-159.

Ross, P.I., AND M. G. Jalkotzy. 1996. Cougar predation on moose in Southwestern Alberta. Alces 32:1-8.

Schaller, G. B., ANd P. G. CRawshaw. 1980. Movement patterns of jaguars. Biotropica 12:161168.

Selva, N., B. Jędrzejewska, W. Jędrzejewski, and A. Wajrak. 2005. Factors affecting carcass use by a guild of scavengers in European temperate woodland. Canadian Journal of Zoology 83:1590-1601.

Silveira, R. D., E. E. Ramalho, J. B. Thorbjarnarson, and W. E. Magnusson. 2010. Depredation by Jaguars on Caimans and Importance of Reptiles in the Diet of Jaguar. Journal of Herpetology 44:418-424.

Skinner, J. D., And C. T. Chimimba. 2005. The Mammals of the Southern African Subregion. Cambridge University Press. Cambridge, United Kingdom.

Sunquist, M. E., AND F. C. Sunquist. 1989. Ecological constraints on predation by large felids. Pp. 283-301 in Carnivore Behavior Ecology and Evolution (Gittleman, J. L., ed.). Cornell University Press. Ithaca, U.S.A.

Sundquist M. E., AND F. C. Sunquist. 2002. Wild cats of the world. University of chicago press. Chicago. U.S. A.

Taber, A. B., A. J. Novaro, N. Neris, and F. H. Colman. 1997. The Food Habits of Sympatric Jaguar and Puma in the Paraguayan Chaco. Biotropica 29:204-213.

Veríssimo, D., D. A. Jones, R. Chaverri, And S. R. Meyer. 2012. Jaguar Panthera onca predation of marine turtles: conflict between flagship species in Tortuguero, Costa Rica. Oryx 46:340-347.

WeCkel, M., W. Giuliano, and S. Silver. 2006. Jaguar (Panthera onca) feeding ecology: distribution of predator and prey through time and space. Journal of Zoology 270:25-30.

Wilmers, C. C., R. L. Crabtree, D. W. Smith, K. M. Murphy, and W. M. Getz. 2003. Trophic facilitation by introduced top predators: grey wolf subsidies to scavengers in Yellowstone National Park. Journal of Animal Ecology 72:909-916.

Wilson, E. E., AND E. M. Wolkovich. 2011. Scavenging: how carnivores and carrion structure communities. Trends in Ecology and Evolution 3:1-7.

Submited: January 3, 2016

Reviewed: April 15, 2016

Accepted: April 18, 2016

Associated editor: William Lidiker 
